\title{
海浜公園池における地域未利用資源を 活用した底質改善による栄養塩制御
}

\author{
吾妻 咲季 $1 \cdot$ 村上 和仁 $2 \cdot$ 五明 美智男 $3 \cdot$ 天野 佳正 4

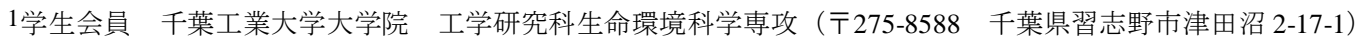 \\ E-mail: s1373001KH@s.chibakoudai.jp \\ 2 正会員 千葉工業大学 工学部生命環境科学科（下275-8588 千葉県習志野市津田沼 2-17-1） \\ E-mail: kaz_murakami@ @sky.it-chiba.ac.jp \\ 3 フェロー 千葉工業大学 工学部生命環境科学科（广275-8588 千葉県習志野市津田沼 2-17-1） \\ E-mail: michio.gomyo@it-chiba.ac.jp \\ 4 千葉大学大学院工学研究科共生応用化学専攻（厂263-8522 千葉県千葉市弥生町 1-33） \\ E-mail: amanoy@faculty.chiba-u.jp
}

\begin{abstract}
千葉県九十九里海岸沿いに位置している蓮沼海浜公園ボート池において，過去にアオコが発生し， 景観の悪化や悪臭問題が起きた。このアオコの優占種は藍藻類 Anabeana spiroides であり, 空中窒素固 定能という機能を有しているため，水中にリンさえあれば爆発的に増殖が可能である. 本研究では, 九十九里海岸に多く散乱している地域未利用資源である貝殼を用いて貝殼の成分である Ca とリンを吸 着させ，富栄養化からの改善を目的として検討を行った。リンの抑制率において，30４0\%の抑制効果 がみられた。 5 30 $/ \mathrm{m}^{2} ・ 50 〜 90 \mathrm{~g} / \mathrm{m}^{2}$ 散布系において抑制率に変化がみられなかった. COD 抑制率にお いては, 貝殼を散布したことにより植物プランクトンの増殖が抑制されたため, 散布量が多くなるに つれ高い值を示した.
\end{abstract}

Key Words: shell, phosphorus removal, regional unused resources, enclosed sea area, water quality improvement

\section{1.はじめに}

日本の湖沼は, 河川・海域に比べて環境基準 （COD または BOD）の達成率が低く, 富栄養化が 進行した状態にある ${ }^{1)}$. 図-1 は河川・海域・湖沼の 環境基準達成率の経年変化が示されている. 平成 22 年度において, 河川では $92.5 \%$, 海域では $78.3 \%$ と 高い達成率であるが，湖沼は $53.2 \%$ と低い值を示し ている.この理由として湖沼が閉鎖的環境であり， 栄養塩の供給が河川からの流入に加えて, 底泥から の溶出が大きく寄与しているからである. 富栄養化 対策はいくつも提案・実施されているが，コストや 維持管理などの問題があり進んでいないのが現状で あり，例えば，千葉県は県下に手賀沼・印旛沼とい う全国的にも有名な富栄養化湖沼をかかえ, 大規模 な浚渫や導水事業などによる水環境の修復に取り組 んできた。

湖沼の富栄養化対策として，物理的な方法には底 泥処理 (浚渫 - 覆砂) や浄化用水の導入, 流入水の流 路変更などがあるが, 維持管理やコストの問題が挙 げられ，生物学的な方法としては魚類の除去がある が生態系の崩壊という問題が懸念されている。した がって, 現在では維持管理やコストの低減，生態系 の維持が両立できる浄化法が求められている.

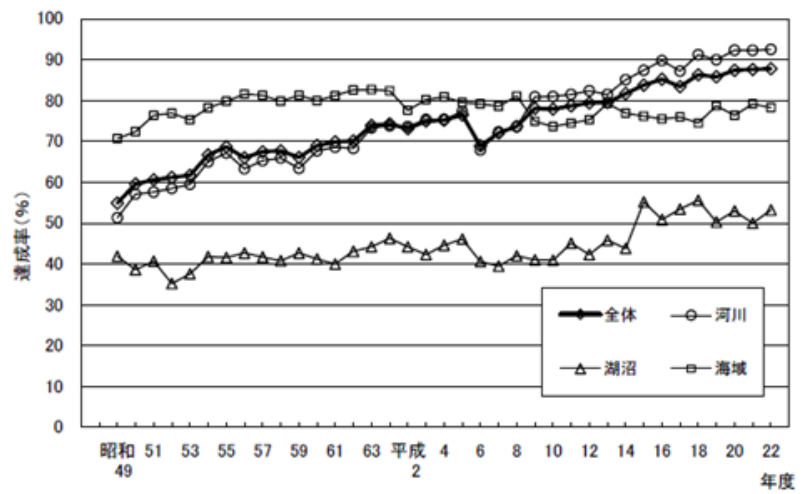

図-1 環境基準達成率（COD または $\mathrm{BOD）}$ の経年変化 (平成 22 年度 環境省より)

\section{2. 蓮沼海浜公園の概要}

千葉県山武市にある蓮沼海浜公園ボート池 (図-2) は，九十九里浜より $350 \mathrm{~m}$ 内陸に位置した海浜/砂質 地帯であり，池の表面積は約 $10,000 \mathrm{~m}^{2} ，$ 水の容積は $7,400 \mathrm{~m}^{3}$ ，水深は $0.74 \mathrm{~m}$ の閉鎖性の強い汽水池であ $ろ^{2)}$.

過去にレジャー施設として貸しボートを営業して いたが，1990 年頃から水量調節を行っていたポンプ の故障により夏季にアオコが発生し, 景観の悪化や 悪臭などの問題が生じ，現在は貸しボートを休業し 
ている(図-3). 過去に天日干しや水抜きなどの改善 工事を行ったが夏季にはアオコが発生している ${ }^{3)}$. 蓮沼海浜公園池のアオコの優占種は, 藍藻類 Anabeana spiroides（図-4）である。この Anabeana spiroides は空中窒素固定能を有しているため, 水中 にリンさえあれば増殖が可能である。

蓮沼海浜公園ボート池近くの九十九里海岸には多 くの貝殼が散乱している. 貝殼の成分である Ca に は, 以下の化学式(1)のようにリンを吸着する特性 がある。

$$
\begin{aligned}
\mathrm{Ca}^{2+}+\mathrm{HPO}_{4}{ }^{2-} & +3 \mathrm{H}_{2} \mathrm{O} \\
& \rightarrow \mathrm{CaHPO}_{4} \cdot 3 \mathrm{H}_{2} \mathrm{O} \downarrow
\end{aligned}
$$

貝款は産業廃棄物として毎年大量に破棄されてお り，これらの貝殼を使用することで，水質浄化およ び産業廃棄物の低減が可能になると考えられる。本 研究では, 九十九里海岸に多く散乱している地域未 利用資源である貝殸 (アカガイ Anadara broughtonii) の主成分である $\mathrm{Ca}$ に着目し, 富栄養化の原因物質 であるリンを貝殸との物理的吸着および貝殼から溶 出した $\mathrm{Ca}^{2+}$ との化学結合により除去し, 水質の富栄 養化状態からの改善を目的とした。

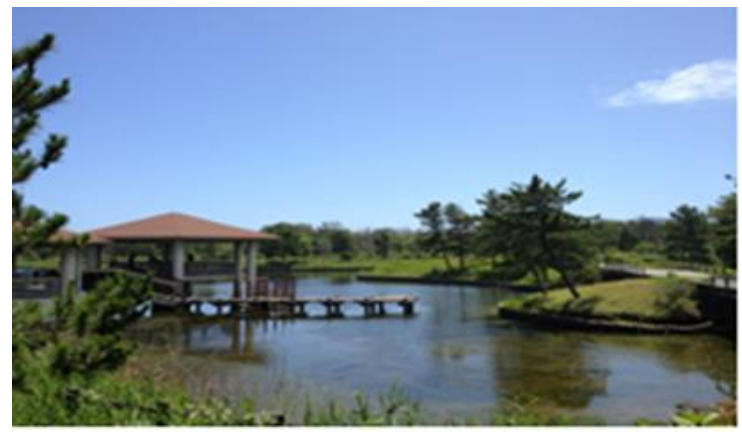

図-2 蓮沼海浜公園ボート池

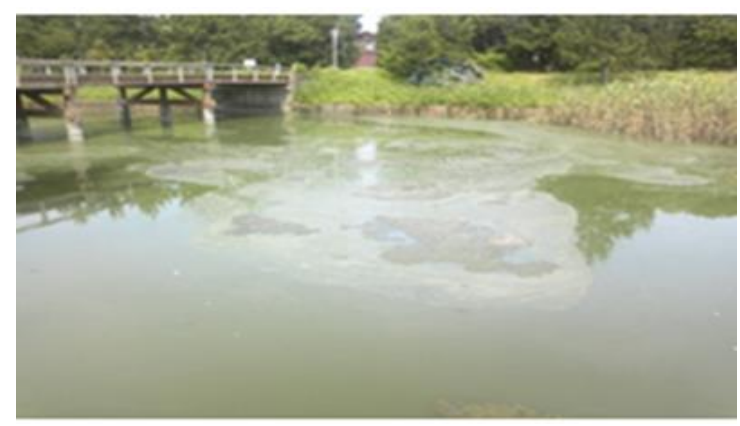

図-3 アオコ発生時の蓮沼海浜公園ボート池

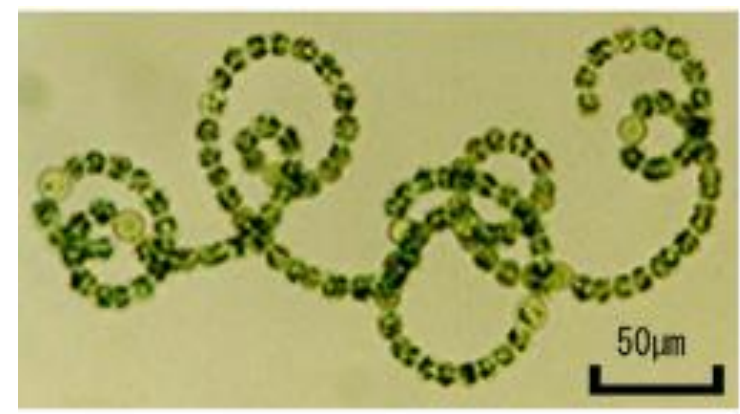

図-4 Anabeana spiroides

\section{3. 供試地域未利用資源}

地域未利用資源としてアカガイ (Anadara broughtonii) を使用した。アカガイはフネガイ目フ ネガイ科に属する二枚貝の一種である. 内湾の干潮 帯や浅海の砂泥底に潜って生息しており, 款には 42 本前後の放射肋があり, エリスロクルオリンとい うへモグロビンに似た成分が含まれているため血液 が赤いのが特徵である。この貝殼を 1-3mm の大き さに粉砕し(図-5), 栄養塩類の供給源である底泥 表面に散布した。なお，この貝殼は隣接する九十九 里海岸に多く散乱しており, 白い外見から底泥に散 布した際に光が反射して底泥表面が明るくみえ，水 の透明度が向上したように感じる効果も期待できる。

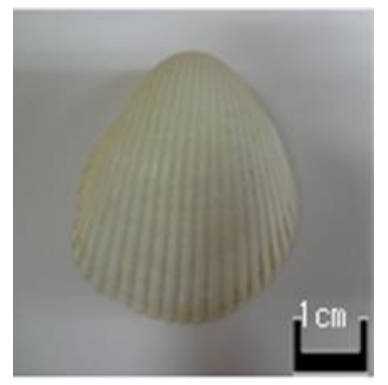

図-4 アカガイ (Anadara broughtonii)

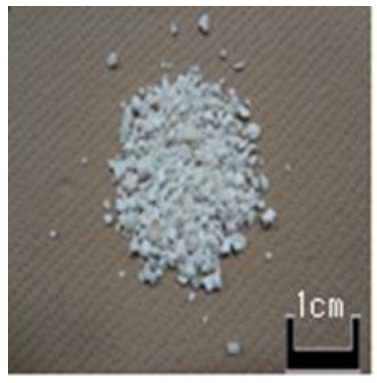

図-5 粉砕した貝殻

\section{4. 実験方法}

マイクロコズム試験における水量は 300～1,000ml が一般的であるので ${ }^{4)}$, 本研究では透明ガラス容器 (高さ: $14 \mathrm{~cm}$, 直径 : $7 \mathrm{~cm}$, 容量 : $470 \mathrm{ml}$ ) (図-6)を使 用した. 現地より採取した底泥 $100 \mathrm{~g}$ を容器の底に 平坦になるように充填した上で環境水 $380 \mathrm{ml}$ を底泥 を乱すことなく注ぎ，定温インキュベータにて培養 した. 培養条件は, 温度 $25^{\circ} \mathrm{C}$, 照度 $2,400 \mathrm{Lux}$, 明暗 周期 $(\mathrm{L} / \mathrm{D}=12 / 12 \mathrm{hr})$ ，静置培養，培養期間は 20 日間 とした. 分析項目は, T-N, T-P, $\mathrm{NH}_{4}-\mathrm{N}, \mathrm{NO}_{3}-\mathrm{N}$, $\mathrm{NO}_{2}-\mathrm{N}, \mathrm{PO}_{4}-\mathrm{P}, \mathrm{Chl} . \mathrm{a}, \mathrm{COD}, \mathrm{pH}, \mathrm{DO}, \mathrm{IL}$ (底泥)， 硬度 $(\mathrm{Ca}+\mathrm{Mg})$ ，植物プランクトン相とした。硬度は キレート滴定 (JIS K0102) により測定し, 植物プラン クトン相の観察は 0， 5，10，15，20 日目に行った.

培養系は 0 (非散布系)，5，10，20，30，50，80，90， $100 \mathrm{~g} / \mathrm{m}^{2}$ 散布系の 9 系とした.

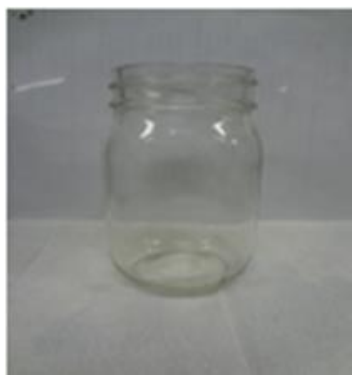

図-6 透明ガラス容器

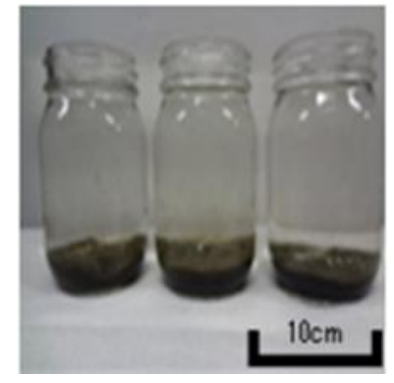

図-7 評価系としての マイクロコズム 


\section{5. 結果および考察}

\section{（1） リンの吸着}

リンの抑制率を図-8，9 に示した。 このグラフよ り散布量が多いほど抑制率は高い值を示し, 最高で T-Pにおいて $34.9 \%, \mathrm{PO}_{4}-\mathrm{P}$ において $28.0 \%$ の抑制率 となった。この結果より，貝殼を散布したことによ り貝殼の成分である $\mathrm{Ca}$ が前述の (1) 式のようにリン を吸着した可能性が考えられる。

T-Pにおいて 5 30 $/ \mathrm{m}^{2} ・ 50 \sim 90 \mathrm{~g} / \mathrm{m}^{2}$ 散布系の間で 抑制率の值がほぼ一定であることが示された。この 結果により，それぞれこの間の散布量であるならば, 抑制率に変化がないことがわかった。

散布量が多くなるに伴い，抑制率は上がっている が， $80 \mathrm{~g} / \mathrm{m}^{2} \sim 100 \mathrm{~g} / \mathrm{m}^{2}$ 散布系においては抑制率が下が っている結果となった。この理由として散布量が多 くなることにより散布したとき貝殼同士が重なりあ ってしまうため, 吸着する表面積が減少したためと 考えられる。

貝款 $\left(\mathrm{CaCO}_{3}\right)$ の水中 $\left(25^{\circ} \mathrm{C}\right)$ における溶解度積を算 出したところ以下の式(2)のようになった.これより, 底泥から溶出したリンと貝殼から溶出した $\mathrm{Ca}^{2+}$ の結 合吸着量は非常に微量であるため, 本実験における リン濃度の減少は主に貝殼との物理的吸着によるも のと考えられた。

$$
\left[\mathrm{Ca}^{2^{+}}\right]\left[\mathrm{CO}_{3}{ }^{2^{-}}\right]=\left(3.6 \times 10^{-9}\right)^{2}(\mathrm{~mol} / \mathrm{L})
$$

\section{(2) $N / P$ 比}

リービッヒの最少律によれば，栄養塩の中でも最 も不足する物質が制限因子となり植物プランクトン の増殖量を支配すると言われている. N, P の現存量 と同時に, N/P 比の変化は植物プランクトンの分布 や種組成に影響し, そして水圈生態系に影響を与え ることも懸念されている. よって N/P 比は制限因子 を判断したり, 生態系との関連を調べる上で重要と されている5).

N/P 比の結果を図-10 13 に示した.すべての系で 未処理系と比べて散布量が多くなるにつれて N/P 比 は高い值となった。この結果より，貝殼を散布した ことにより Ca がリンを吸着し, N/P 比が高くなった と考えられ, P 過多から適正 N/P 比の方向へと変化 した。しかし，すべての系で N/P 比が 2.0 以下とい う低い值であるため，未だリン過多の富栄養化状態 であることが示されている.

一般に, N/P 比は 10 程度が適正とされており，千 葉県下の全国的に有名な富栄養化湖沼である印旛 沼・手賀沼においても，夏季の N/P 比は 8.5 前後で ある ${ }^{5)}$. しかし, 例年蓮沼海浜公園ボート池におけ る N/P 比は通常 2.5 以下というきわめてリン過多な 状況にあり,さらにアオコの優占種である Anabeana spiroides は空中窒素固定能によりリンさえ存在すれ ば増殖可能なため, 蓮沼海浜公園ボート池において リン過多な状況は深刻な問題となっている.

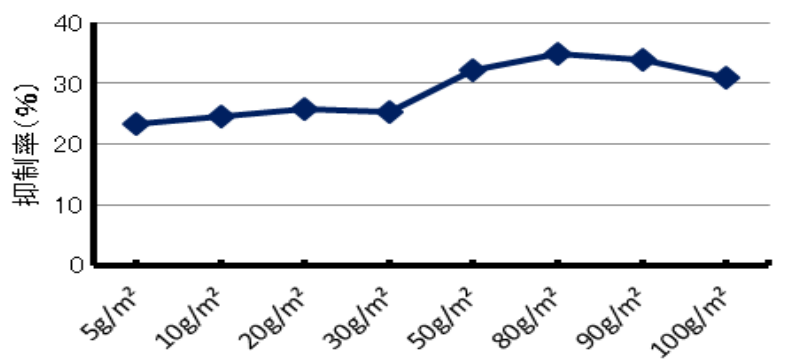

図-8 各系における T-P の抑制率

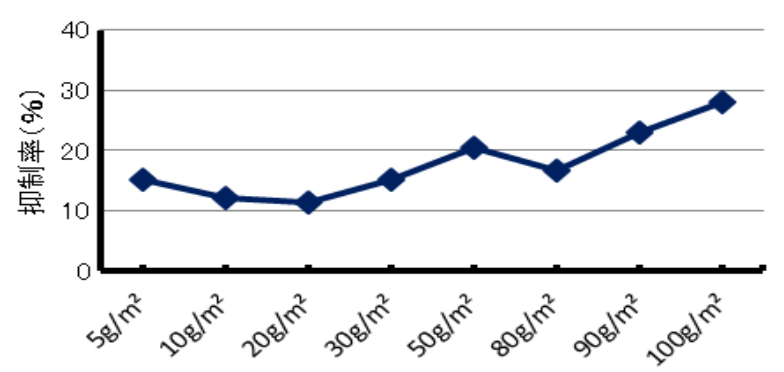

図-9 各系における $\mathrm{PO}_{4}-\mathrm{P}$ の抑制率

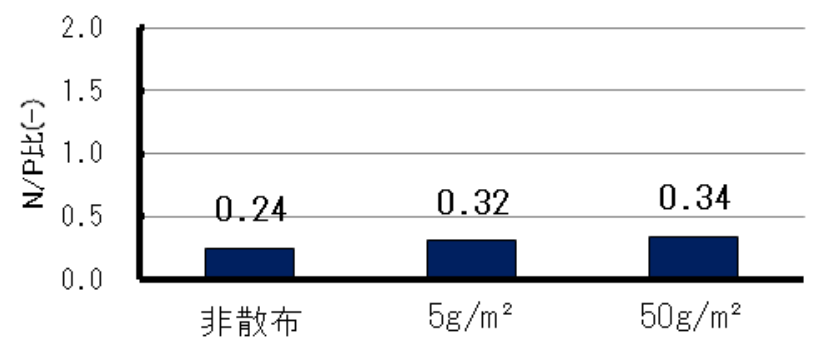

図-10 $5 \mathrm{~g} / \mathrm{m}^{2} \cdot 50 \mathrm{~g} / \mathrm{m}^{2}$ における N/P 比

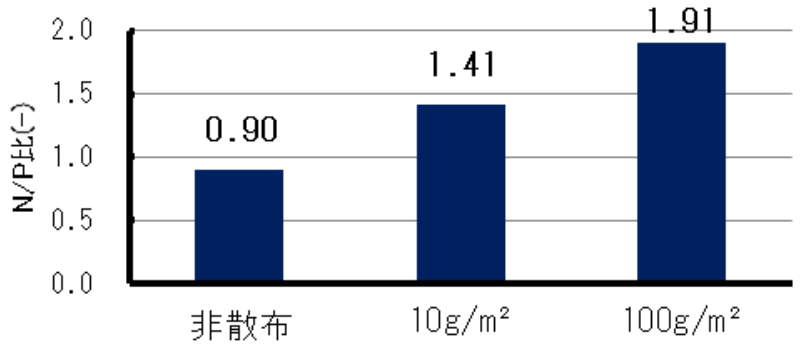

図-11 $10 \mathrm{~g} / \mathrm{m}^{2} \cdot 100 \mathrm{~g} / \mathrm{m}^{2}$ における $\mathrm{N} / \mathrm{P}$ 比

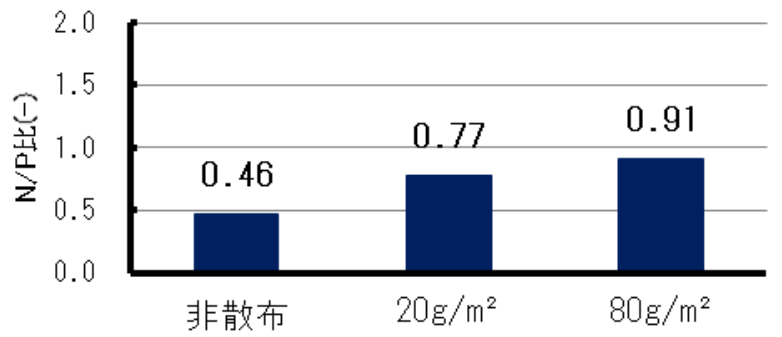

図-12 $20 \mathrm{~g} / \mathrm{m}^{2} \cdot 80 \mathrm{~g} / \mathrm{m}^{2}$ における N/P 比

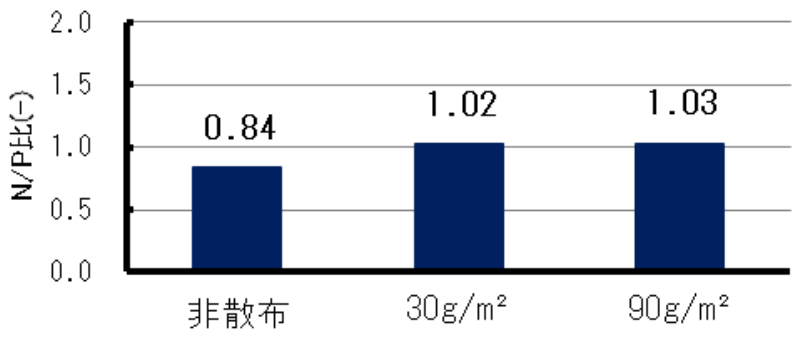

図-13 $30 \mathrm{~g} / \mathrm{m}^{2} \cdot 90 \mathrm{~g} / \mathrm{m}^{2}$ における N/P 比 
（3）地域未利用資源と植物プランクトンの関係

植物プランクトンの経日変化を図-14〜17 に示し た.すべての系において優占種は Chlorella sp.であっ た.グラフより, 各散布系において, 5 日もしくは 10 日目までは非散布系よりも個体数が少ないこと が示された。この結果は, 貝殼の成分である $\mathrm{Ca}$ が 水中に溶出したことによりリンと結合し, リン濃度 を低減させたため, 植物プランクトンの増殖が抑制 され個体数が減少したものと考えられる. 本実験池 において, 東日本大震災の発生により津波が流入し, 夏季における Anabeana spiroides を優占種とするア オコの増殖は抑制されているが, 現在は震災前の水 質に戻りつつあるため, 再びアオコの発生が起こる ことが危惧されている. よって本研究において植物 プランクトンの増殖が抑制されたように，貝殼散布 によるリン抑制は Anabeana spiroides のような特殊 な機能を有しているアオコ形成植物プランクトンの 抑制に有効な手段となるものと考えられる.

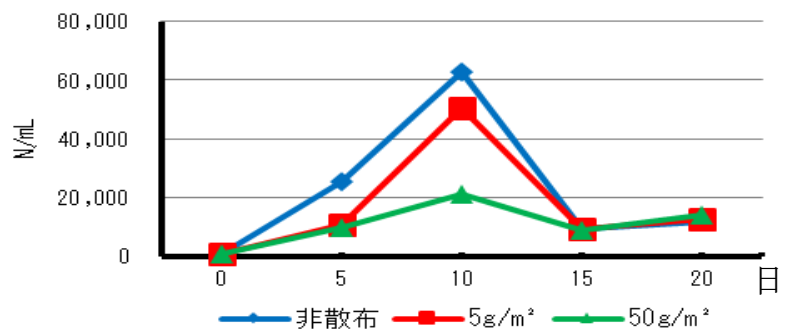

図-14 $5 \mathrm{~g} / \mathrm{m}^{2} \cdot 50 \mathrm{~g} / \mathrm{m}^{2}$ における植物プランクトン相

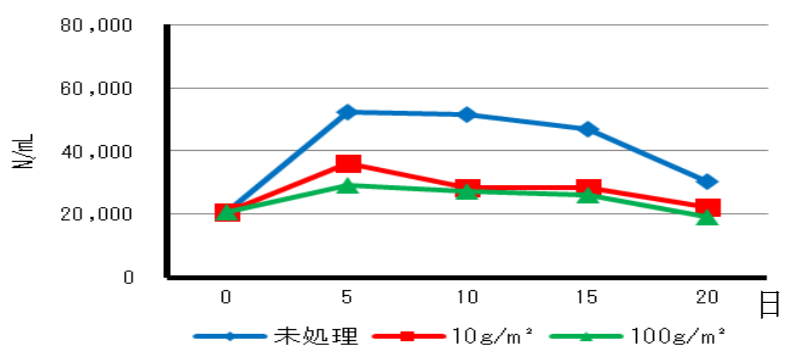

図-15 $10 \mathrm{~g} / \mathrm{m}^{2} \cdot 100 \mathrm{~g} / \mathrm{m}^{2}$ における植物プランクトン相

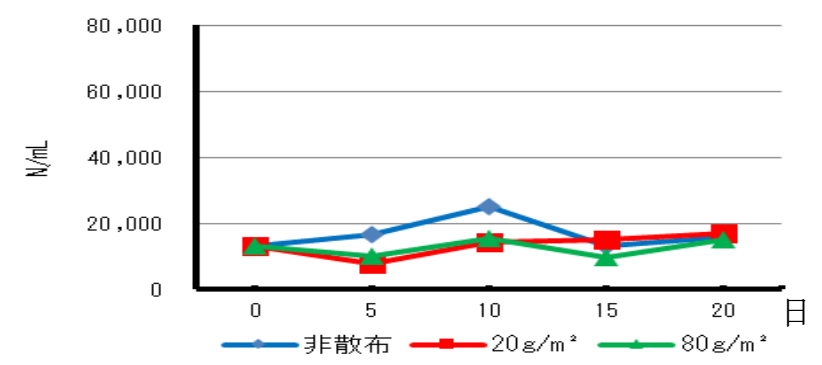

図-16 $20 \mathrm{~g} / \mathrm{m}^{2} ・ 80 \mathrm{~g} / \mathrm{m}^{2}$ における植物プランクトン相

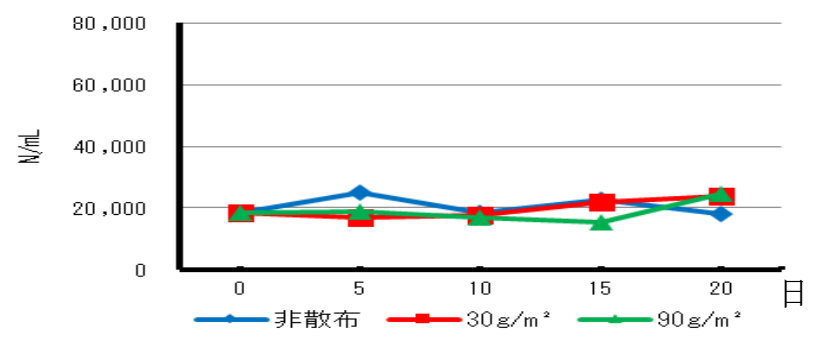

図-17 $30 \mathrm{~g} / \mathrm{m}^{2} \cdot 90 \mathrm{~g} / \mathrm{m}^{2}$ における植物プランクトン相

\section{（4）硬度}

硬度測定の結果を図-18〜22 に示した. 各グラフ において散布量が多いほど硬度は高い值を示した。 この結果より，貝殼を散布したことで貝殼の成分で ある $\mathrm{Ca}^{2+}$ が水中に溶出したことが裏付けられた. 水 中において貝款の成分である $\mathrm{CaCO}_{3}$ は，水中に溶 け込んでいる $\mathrm{CO}_{2}$ 量が多いと溶出しやすくなる. 本 実験においては貝殼散布に伴う植物プランクトンの 増殖抑制により光合成量が減少し, DO 值が $5.0 \mathrm{mg} / \mathrm{L}$ 程度の低い值となっている。これにより貧酸素の雰 囲気となり水中に $\mathrm{Ca}^{2+}$ が溶出したものと考えられる.
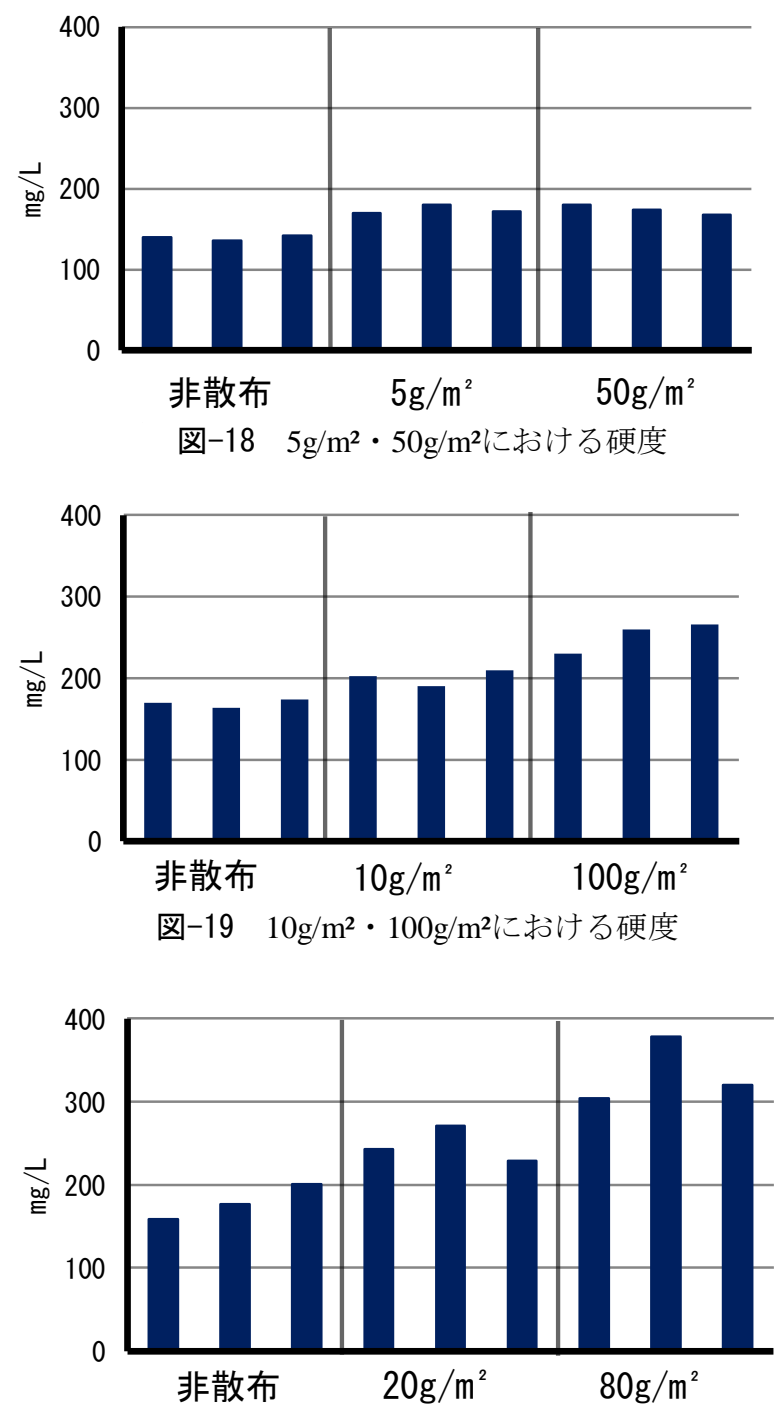

図-20 20g/ $\mathrm{m}^{2} \cdot 80 \mathrm{~g} / \mathrm{m}^{2}$ における硬度

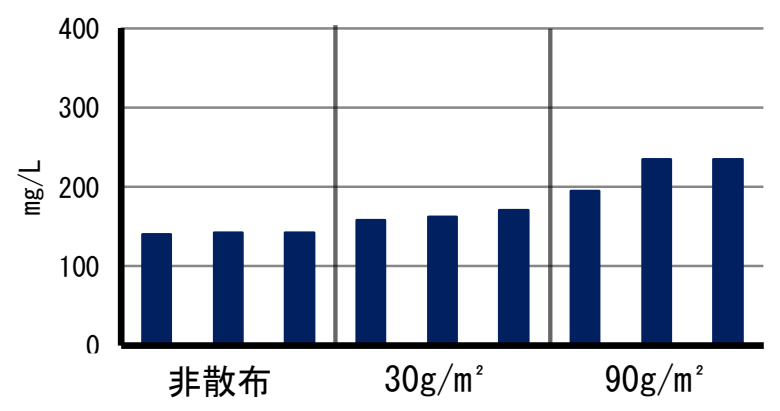

図-21 30g/m² $90 \mathrm{~g} / \mathrm{m}^{2}$ における硬度 


\section{(5) $\mathrm{pH}$}

図-22〜25 に各散布系における $\mathrm{pH}$ を示した。 $\mathrm{pH}$ は 8〜9 であり散布に伴う急激な変動はみられなか った。この結果は貝殼の有効利用における水質浄化 実験 ${ }^{9)}$, リン酸溶液 $\left(\mathrm{KH}_{2} \mathrm{PO}_{4} \quad 100 \mathrm{mg} / \mathrm{L}\right.$ に貝殼 $1 \mathrm{~g}$ 散 布)のみでの実験においても同様であった.この理由 として, $\mathrm{CaCO}_{3}$ が水中に溶解すると, 以下の式(3) のようになる。

$$
\mathrm{CaCO}_{3}+2 \mathrm{H}_{2} \mathrm{O} \rightarrow \mathrm{Ca}(\mathrm{OH})_{2}+\mathrm{H}_{2} \mathrm{CO}_{3}
$$

ここで, $\mathrm{Ca}(\mathrm{OH})_{2}$ は酸性, $\mathrm{H}_{2} \mathrm{CO}_{3}$ はアルカリ性であ るため, 水質が中性になり, $\mathrm{pH}$ の急激な変動がみら れなかったものと考えられる.これより, $\mathrm{pH}$ の低下 は植物プランクトンの増殖を抑制する程度のもので はなく, 植物プランクトンの増殖抑制は散布した貝 殼のリン吸着による栄養塩濃度減少によるものと考 えられる。

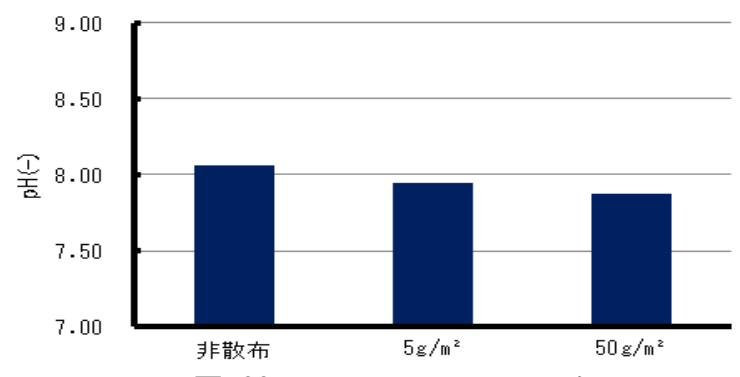

図-22 $5 \mathrm{~g} / \mathrm{m}^{2} \cdot 50 \mathrm{~g} / \mathrm{m}^{2}$ における $\mathrm{pH}$

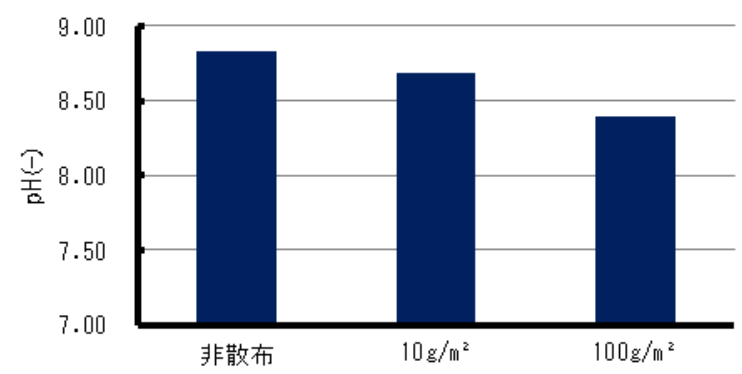

図-23 $10 \mathrm{~g} / \mathrm{m}^{2} ・ 100 \mathrm{~g} / \mathrm{m}^{2}$ における $\mathrm{pH}$

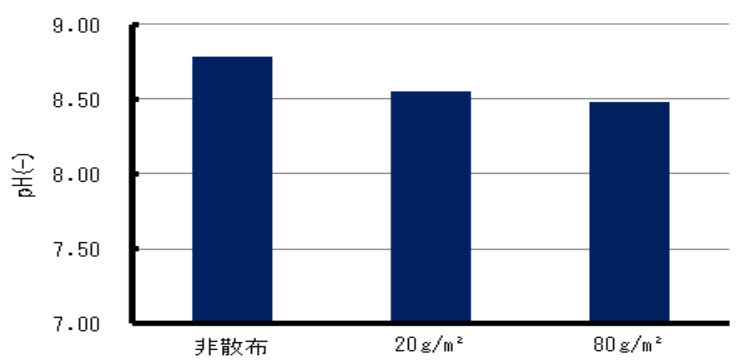

図-24 $20 \mathrm{~g} / \mathrm{m}^{2} ・ 80 \mathrm{~g} / \mathrm{m}^{2}$ における $\mathrm{pH}$

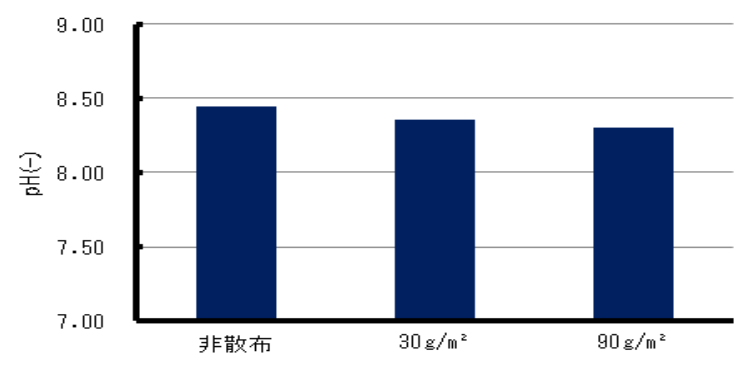

図-25 30 $/ \mathrm{m}^{2} \cdot 90 \mathrm{~g} / \mathrm{m}^{2}$ における $\mathrm{pH}$

\section{（6）散布量と COD 抑制率の関係}

図-22に各散布系におけるCOD の抑制率を示した。 これより, 散布量に比例して COD 抑制率が高くな る結果となった。これは，貝殼を散布したことによ り $\mathrm{Ca}$ が溶出し，栄養塩類である $\mathrm{P}$ と結合して植物 プランクトンの増殖が抑制され，水中の有機物量が 減少したために COD 抑制率が高くなったものと考 えられる。

\section{（7） 今後の展開}

本研究では，焼成等を施さない未処置の地域未利 用資源（貝殼）を用いたため，リンの吸着率が $40 \%$ 以下となっており，高い除去効率とは言えない状態 である，今後，地域未利用資源である貝殼を焼成処 理等により吸着除去効率を向上させ ${ }^{5-8)}$, それらを散 布して底質改善を行うことの検討が必要である。ま た, 従来より底質改善材として $\mathrm{MgO}$ や $\mathrm{CaO}$ の散布 に関するモデルエコシステム (図-23)での実験研究 により，処理特性および効果について検討されてお り, 長期的な抑制効果としては $\mathrm{CaO}$ 散布が有効であ ることが示されている ${ }^{10,11)}$.これらの研究との比較 を行うとともに，地域未利用資源 (貝款)の適正散布 量の検討を行う必要がある。ささらに，地域未利用資 源である貝款を富栄養化が進行したへドロ状の底泥 表面に散布することにより，ヨシ等の水生植物の植 栽の際の基底を形成できる可能性 ${ }^{11} に$ にいても検討 の余地があり，散布した貝殼にリンが吸着できてい れば高栄養価の基底材となることが考えられる，富 栄養化湖沼の環境修復の一手段としての人工湿地の 造成やビオトープ化への足掛かりとして今後検討し ていく予定である.

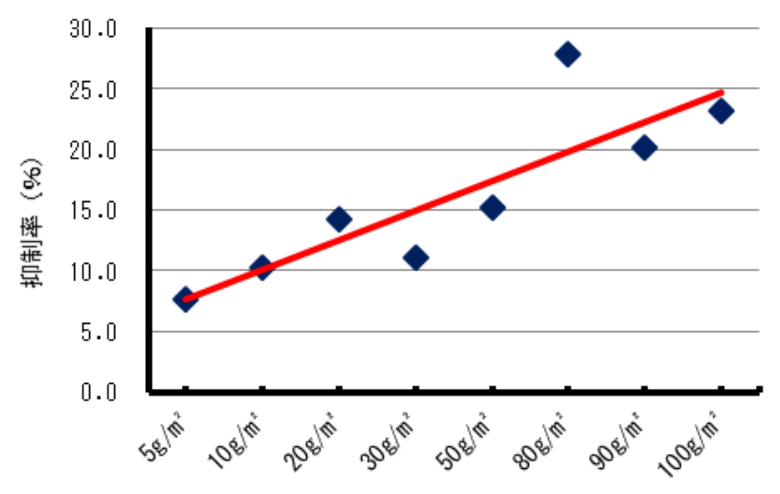

図-26 各散布系における COD の抑制率

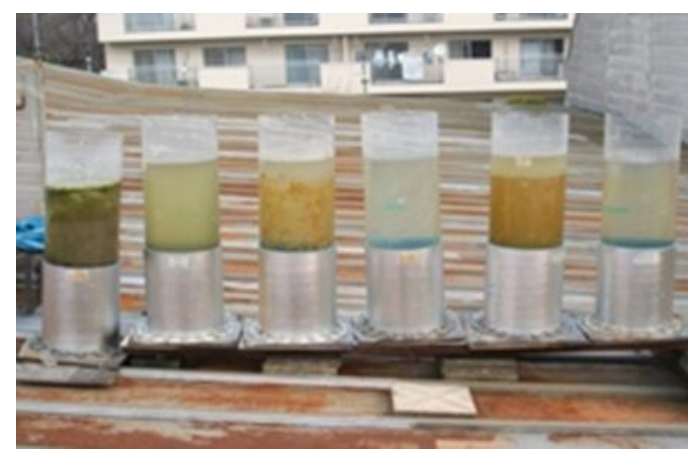

図-27＼cjkstart野外設置型モデルエコシステム 


\section{6. まとめ}

本研究は, 九十九里海岸に多く散乱している地域 未利用資源である貝殼 (アカガイ Anadara broughtonii）の主成分である Caに着目し, 富栄養化 の原因物質であるリンを貝殼との物理的吸着および 貝殼から溶出した $\mathrm{Ca}^{2+}$ との化学結合により除去し, 水質の富栄養化状態からの改善を目的として検討し たものである。得られた成果は以下のようにまとめ られる。

1) 地域未利用資源である貝殼を散布することによ り，貝殼との物理的吸着および貝殼から溶出した $\mathrm{Ca}^{2+}$ との化学結合により，富栄養化物質であるリ ンが抑制（T-P : 30〜 40\%）された.

2) 貝殼の散布量について，5～30 g/m² $90 \mathrm{~g} / \mathrm{m}^{2}$ の範囲でそれぞれ T-P の抑制率に変化がみ られなかった。

3) 貝殼散布に伴い, N/P 比は適正 N/P 比の方向へと 緩和されたが,すべての系において N/P 比 2.0 以下 であり，リン過多の状態であった。

4) COD 抑制率は, 貝殼散布による栄養塩 (特にリン) の吸着除去により植物プランクトン現存量が減少 して水中の有機物が減少したことにより，散布量 が多いほよ゙高くなった。

5) 植物プランクトンの優占種はいずれの系におい ても Chlorella sp.であったが, 貝殼散布に伴って栄 養塩であるリン濃度が低減したため, 散布量が多 くなるに伴い個体数が減少した。

追記 : 本研究の一部は, 日本学術振興会平成 $24 \sim 26$ 年度 科学研究費助成事業（学術研究助成基金助成金）（挑戦的 萌芽研究）（課題番号 24651029）「移入種生物がもたら す生態系影響評価のためのモデルエコシステムの汎用化 に関する研究（代表 : 村上和仁）」として実施された.

謝辞：本研究を遂行するにあたり、千葉県山武市地域整 備センターの関係各位に多大なるご理解とご協力を賜っ た。ここに記して感謝の意を表する。

\section{参考文献}

1) 環境省：環境白書（平成 24 年度版）

http://www.env.go.jp/policy/hakusyo/h24/pdf.html

2) 村上和仁、石井俊夫、瀧 和夫 : 海浜公園池 (汽水湖) における水の華と栄養塩負荷特性, 土木学会海洋開発論 文集, 24 巻, pp.633-638, 2008.

3) 村上和仁, 石井俊夫, 瀧 和夫 : 強閉鎖性で浅い海浜公 園池における底泥の天日干しによる水質の摇り戻し現 象, 環境情報科学論文集, 23 巻, pp.435-440, 2009.

4) Y.Amano, K.Taki, K.Murakami, T.Ishii, H.Matsushima : Sediment Remediation for Ecosystem in Eutrophicated Lakes, The Scientific World, Vol.2, pp.885-891, 2002.

5) 二宮勝幸，柏木宣久，安藤晴夫，小倉久子 : 植物プラ ンクトンの増殖に伴う N/P 比の変化に関する理論的考 察および東京湾における N/P 比の空間分布の季節別特 徵, 横浜市環境科学研究所報第 24 号, pp62-70, 2000

6) 高橋典子 : 未利用資源を活用した生物膜法における水 質浄化特性, 東邦大学特別問題研究報告書, 1996.

7) R.Yuangsawad, D.Na-Ranong : Recycling Oyster Shell as Adsorbent for Phosphate Removal, The 21st Thai Institute of Chemical Engineering and Applied Chemistry, November 10 $-11,2011$.

http://chemserver.eng.psu.ac.th/tiche2011/TCHE/data/paper/ international/sp/oral/sp008.pdf

8) W.H.Park, C.Polprasert : Phosphorus Adsorption Characteristics of Oyster Shells and Alum Sludge and Their Application for Nutrient Control in Constructed Wetland System, Issue 5 vol.43, pp.511-517, 2008.

9) W.H.Park : Integrated Constructed Wetland System employing Alum Sludge and Oyster Shells as Filter Media for P removal, Ecological Engineering, Vol.35, pp.1275-1282, 2009.

10) 本田晴朗, 寺添 斉: 発電所付着生物の殼を用いた水 質浄化一濾材および吸着材としての特徵一, 電力中央 研究所報告 研究報告(03034), pp.1-9, 2004.

11) 村上和仁, 石井俊夫, 瀧 和夫, 松島眸 : 底泥処理に おける環境修復強度の生物多様性に及ぼす影響, 環境情 報科学論文集, 21 巻, pp.75-80, 2007.

12）村上和仁, 石井俊夫, 瀧 和夫, 松島 眸 : 底泥処理に よる湖沼内部生産の抑制効果, 環境情報科学論文集, 22 巻, pp.487-492, 2008.

13) 中村伸夫 : リサイクル材を活用した底質浄化処理技術 について

http://www.qsr.mlit.go.jp/n-shiryo/kenkyu/02/03.pdf

\title{
NUTRIENT CONTROL BY THE SEDIMENT QUALITY IMPROVEMENT USING UNUSED REAGIONAL RESOURCES IN THE SEASIDE PARK POND
}

\author{
Saki AGATSUMA, Kazuhito MURAKAMI, Michio GOMYO \\ and Yoshimasa AMANO
}

\begin{abstract}
In Hasunuma Seaside Park Pond where is located on the seafront Kujyukurihama coastal line in Chiba, water bloom has occurred in the past, the deterioration of the landscape and odor problems occurred. Dominant species of this Aoko are Cyanophyceae Anabeana spiroides. It has a feature called nitrogen fixation air, the explosive growth can be as long as there is phosphorus in the water. In this study, the shell collected from sandy beach on Kujyukurihama coastal line was applied as regional unused resources for nutrients remove by phosphorus adsorption. In a restraint rate of phosphorus, 30-40\% of suppressant effects were seen. In the COD restraint rate, an increase of the phytoplankton was controlled by having sprayed a shell. Therefore, it showed a high price as quantity of dispersion increased.
\end{abstract}

